індивідуальних, практичних занять, моніторингу якості навчання, під час проведення заліків та іспитів. На практичних заняттях майбутні вчителі музики презентували власне специфічне мислення, спрямоване на вибір творчої дії для реалізації оригінальної художньої інтерпретації самостійно вивченого музичного твору.

Отже, аналіз проведеного діагностувального опитування засвідчує позитивне ставлення та інтерес респондентів до проблеми дослідження, його актуальність для студентів вищих музично-педагогічних навчальних закладів. Статистичне узагальнення здійснювалось за формулою, запропонованою С. Гончаренком для педагогічних досліджень. На основі проведених за означеною формулою обрахувань узагальнена кількість позитивних відповідей становила 69,6 \%, негативних - 19,6 \%, не визначились із відповіддю - 10,8\%.

3 огляду на зазначене вище, переважна більшість респондентів - 79,6 \% від загальної кількості опитаних - продемонструвала певні уміння щодо самостійного створення інтерпретаційної концепції музичного твору, визначила пріоритетним формування виконавської надійності засобом використання методів саморегуляції, а також підвищення рівня фахової майстерності загалом.

Отже, аналіз наведених вище результатів констатувального діагностування засвідчив перевагу середнього та низького рівнів виявлення показників музичновиконавської підготовленості майбутніх учителів музики. Понад третину респондентів віднесено до низького рівня музично-виконавської підготовленості студентів. Такі результати діагностування вимагають проведення спеціальної педагогічної роботи з використанням сугестивних технологій.

\title{
Література
}

1. Немов Р. С. Психология : [учеб. пособие для высш. учеб. заведений]. - В 3-х кн. - Кн. 3.: Психодиагностика: Введение в научное психологическое исследование с элементами математической статистики / Роберт Семенович Немов. - М. : ВЛАДОС, 1998. - 630, [1] c. 2. Петрушин В. И. Музыкальная психотерапия: Теория и практика : [учеб. пособие для студ. высш. учеб, заведений] / В. И. Петрушин. - М. : Гуманит. изд. центр ВЛАДОС, 2000.- 176 с. 3. Психологические тесты / под ред. А. А. Карелина : В 2-х т. - М. : ВЛАДОС, 2003. - Т. 2. 248 с. 4. Психологія : [підручник] / Ю. Л. Трофімов, В. В. Рибалка, П. А. Гончарук та ін. ; за ред. Ю. Л. Трофімова. - [4-е вид. $]$ - К. : Либідь, 2003. - 560 с. 5. Рудницька О. П. Педагогіка: загальна та мистецька : [навч. посіб.] / О. П. Рудницька. - К. : ТОВ «Інртерпроф», 2002. - 270 с. 6. Щолокова О. Мистецька освіта у контексті сучасних наукових досліджень / О. П. Щолокова / Професійно-художня освіта України : [зб. наук. праць]/ Редкол. : $\quad$ І. А. Зязюн (голова), В. О. Радкевич, Н. М. Чепурна (заступники голови) та ін. - К. : Вид-во «Черкаський ЦНТЕІ», 2007. - Вип. IV. C. $12-16$.

Іванна Размолодчикова

\section{ПЕДАГОГІЧНА ЗАДАЧА ЯК ЗАСІБ ДИДАКТИЧНОЇ ПІДГОТОВКИ МАЙБУТНІХ УЧИТЕЛІВ ПОЧАТКОВИХ КЛАСІВ}

Размолодчикова I. В. Педагогічна задача як засіб дидактичної підготовки майбутніх учителів початкових класів.

У статті подано методичні рекомендації щодо застосування педагогічних задач (ситуацій) як засобу організації навчальної і науково-дослідної роботи майбутніх 
учителів початкових класів. Розкрито сутність понять «задача», «педагогічна задача», «педагогічна ситуація». Наведено класифікацію навчальних педагогічних завдань, які бажано використовувати на початковому етапі підготовки спеціалістів.

Ключові слова: педагогічна задача, дидактичний засіб, процес навчання, професійна підготовка, вчитель початкових класів.

Размолодчикова И. В. Педагогическая задача как средство дидактической подготовки будущих учителей начальных классов.

В статье предложены методические рекомендации по использованию педагогических задач (ситуаций) как средства организации учебной и научноисследовательской работы будущих учителей начальных классов. Раскрыта сущность понятий «задача», «педагогическая задача», «педагогическая ситуация». Приведена классификация учебных педагогических заданий, которые желательно использовать на начальном этапе подготовки специалистов.

Ключевые слова: педагогическая задача, дидактический способ, процесс обучения, профессиональная подготовка, учитель начальных классов.

Razmolodchikova I. V. Pedagogical trade as a means of didactic training of primary school teachers.

This article provides guidelines in usage of pedagogical trades (situations) as means of organization academic and research work of future teachers of primary school. The meaning of concepts are «task», «pedagogical task», «educational situation». Classification of educational pedagogical tasks, which were shown, are desirable to use in the initial phase of the specialists' training quality.

Key words: pedagogical trade, didactic tool, process of learning, professional preparing, teacher of primary school.

Розбудова незалежної Української держави вимагає грунтовної підготовки широкого спектра спеціалістів. У відтворенні продуктивних сил, формуванні інтелектуального потенціалу нації та всебічного розвитку особистості як найбільшої суспільної цінності освіта відіграє визначальну роль.

У Державній програмі «Вчитель» зазначається, що освіта $\epsilon$ «пріоритетною сферою в соціально-економічному, духовному і культурному розвитку Української держави». Ключовою фігурою в системі освіти постає вчитель. Через його діяльність «реалізується державна політика, спрямована на зміцнення інтелектуального і духовного потенціалу нації, розвиток вітчизняної науки i техніки, збереження i примноження культурної спадщини».

Успішне вирішення завдань навчання і виховання безпосередньо пов'язане 3 удосконаленням підготовки педагогів. Жодна інша професія не висуває таких вимог до людини, як професія вчителя. Педагог, учитель, вихователь - довірена особа суспільства, якій воно доручає найдорожче і найцінніше - дітей, свою надію, своє майбутне.

В організації процесу підготовки педагогічних кадрів у ВНЗ особливе місце посідає практична підготовка. Саме вона набуває пріоритетного значення на сучасному етапі розвитку педагогічної освіти України. Водночас аналіз наукових досліджень свідчить, що випускники вишів відчувають серйозні труднощі в спілкуванні з дітьми, їх батьками, своїми колегами. Прийшовши до школи, молоді вчителі стикаються 3 численними проблемами, які вимагають розв'язання, але 
недосвідчені педагоги не знають 3 чого починати. Це відбувається тому, що професійні обов'язки вчителя не були представлені студентам як система конкретних педагогічних задач. ,Отже, ми спостерігаємо розрив між теоретичною підготовкою і практичною діяльністю. Тому активне використання практичних методів, а саме педагогічних задач (ситуацій) у процесі підготовки майбутніх учителів початкових класів може сприяти покращенню ситуації [1, с. 144.].

Дослідженню процесу організації навчання за допомогою задач присвячені праці багатьох науковців: Г. Балла, А. Єсаулова, В. Крутецького, Т. Кудрявцева, Ю. Кулюткіна, О. Леонтьєва, А. Матюшкіна, В. Моляко, Я. Пономарьова, Л. Фрідмана, В. Якуніна. Водночас проблема використання педагогічних задач (проблемних ситуацій) під час підготовки майбутніх учителів початкових класів вимагає додаткового вивчення.

О. Топузов подає таке визначення: «Навчальна задача - це об'єктивна інформація, сформульована в словесній або знаковій формі у співвідношенні між визначеними (відомими) і невизначеними (невідомими) «умовами» [10, с. 55].

Педагогічна задача як навчальна, 3 точки зору Р. Нізамова, - це система інформації про певне явище, об’єкт, процес, у якій чітко визначена лише частина інформації, а остання - невідома, і вона може бути знайдена на основі розв'язання задачі, або інформація сформульована таким чином, що між окремими поняттями, положеннями $є$ неузгодженість, суперечність, що потребують пошуку нових знань, доказу, трансформації, узгодження [6, с. 219].

М. Махмутов звертає увагу не те, що задача - явище об'єктивне і перетворюється на суб'єктивне лише після усвідомлення й сприйняття студентами [5, с. 77]. Він диференціює поняття «пізнавальна задача» на проблемну i непроблемну (згідно із засобами іiі постановки педагогом і іï змістом) і погоджується 3 А. Матюшкіним, що проблемне завдання на відміну від звичайних навчальних задач представляє не просто опис деякої ситуації, що характеризує дані, тобто умови завдання, а вказівку на невідоме, яке має бути установлено на підставі цих умов. У проблемному завданні сам суб'єкт включений у ситуацію розв'язання задачі [4, с. 75$]$.

Mema cmammi - уточнити специфіку процесу використання педагогічних задач як дидактичного засобу підготовки майбутніх учителів початкових класів.

Проаналізувавши педагогічну і методичну літературу, ми визначили, що термін «педагогічна задача» багатозначний. Він використовується для позначення таких категорій, як: завдання (цілі) студентів; завдання, які ставить перед собою викладач; задачі, які пвизначаються для того, щоб їх розв'язок забезпечив досягнення цілей навчання (власне навчальні задачі).

Як правило, педагогічна задача передбачає використання завдань, які мають професійну спрямованість. Наводимо класифікацію навчальних педагогічних завдань, які бажано використовувати на початковому етапі підготовки студентів:

- дати відповіді на запитання, сформульовані щодо певної ситуації;

- вибрати із запропонованих варіантів правильний розв'язок;

- самостійно сформулювати проблему (задачу) на основі заданої педагогічної ситуації;

- підготувати психолого-педагогічну характеристику об'єктів і суб'єктів виховання та їх взаємостосунків у заданій ситуації;

- розв'язати педагогічну задачу на основі педагогічних знань, діагностування i прогнозування поведінки учасників ситуації;

- здійснити пошук або сконструювати педагогічні ситуації з використанням 
літературних джерел або фактів реальної педагогічної практики;

- класифікувати дібрані раніше задачні ситуації з практики навчально-виховної роботи за місцем виникнення i протікання педагогічного процесу (ситуації дидактичні, виховні, навчально-виховні), за суб'єктами й об'єктами, що взаємодіють у ситуації; за закладеними у ситуації виховними перспективами (стратегічні, тактичні, оперативні);

- провести професійно-педагогічний самоаналіз в умовах конкретної ситуації;

- проаналізувати педагогічну ситуацію, використовуючи різні поєднання творчих завдань попереднього типу.

Саме навчальні задачі можуть застосовуватися 3 метою: а) більш доказового роз'яснення на заняттях окремих теоретичних положень; б) повторення, відтворення i закріплення знань; в) контролю і самоконтролю знань і умінь; г) формування вмінь творчого використання знань у нових умовах; д) організації цілеспрямованої підготовки студентів до чергової лекції, семінарського, практичного й іншого заняття; е) ефективної організації використання знань 3 практики і демонстрації практичного значення теоретичних положень.

У ході організації навчальної та науково-дослідної діяльності майбутніх учителів початкової школи педагогічні задачі використовуються на лабораторних i семінарських заняттях.

Наводимо приклади педагогічних задач, які розв'язують студенти на лабораторних заняттях з курсу «Дидактика».

Під час вивчення теми «Процес навчання» використовуємо такі задачі.

Задача 1. На уроці природознавства вивчали овочі. Учителька принесла у клас і поклала на столі картоплю, буряк, моркву, редьку, перець, баклажани, цибулю, часник, помідор, брукву. Учні із захопленням розглядали різноманітність овочів, які були зібрані разом. Вони не знали назву окремих овочів. Учителька запропонувала дітям записати у зошитах назву кожного овоча. Коротко ознайомились, де i як вирощують кожний овоч, для чого його використовують, що можна приготувати 3 окремих овочів.

Робота продовжувалася i на другому уроці. Учителька читала невеличкі оповідання про «життя» тих чи тих овочів, запропонувала учням написати оповідання-казку про улюблений овоч («Як картопля поріднилася 3 квасолею», «Чому почервонів помідор» тощо).

1.Проаналізуйте, яким чином вивчення овочів відповідало вимогам процесу пізнання.

2. Якою мірою на цฺих уроках були реалізовані структурні компоненти процесу учіння?

Задача 2. Уже через тиждень після початку занять у «Школі радості» я сказав малюкам: «Принесіть завтра альбоми й олівці, будемо малювати». Наступного дня ми розташувалися на галявині шкільної садиби. Я запропонував дітям: «Подивіться навколо, що ви бачите гарного, що вам найбільше подобається, те й малюйте».

Перед нами був шкільний сад і дослідна ділянка, освітлені осіннім сонцем. Діти защебетали: одному подобалися червоні й жовті гарбузи, другому - схилені до землі голівки соняшника, третьому - голубник, четвертому - виноградні грона. Шура милувалася легкими пухнастими хмарами, що пливуть у небі. Серьожі подобалися гуси на дзеркальній поверхні ставу. Данькові хотілося намалювати рибок- він натхненно розповідав про те, як одного разу з дядьком ходив на риболовлю: нічого не спіймали, зате побачили, як «грають» рибки. 
- А я хочу намалювати сонечко, - сказала Тіна.

Настала тиша. Діти малювали із захопленням. Я багато читав про методику уроків малювання, а тепер переді мною були живі діти. Я бачив, що дитячий малюнок, процес малювання - це частка духовного життя дитини. Діти не просто переносять на папір щось з навколишнього світу, а живуть у цьому світі, входять у нього як творці краси, дістають насолоду від неї [9, с. 53-54].

1. Учому ви вбачаєте ефективність організачії пізнавальної діяльності учнів у такий спосіб?

2. Розвитку яких якостей сприяє така діяльність школярів?

Під час вивчення теми «Методи навчання» використовуємо такі педагогічні задачі.

Задача 1. На уроці української мови учителька пропонує таку систему запитань:

- Які опади найчастіше - випадають взимку? (Сніг).

- Як називають сніг пестливо? (Сніжок).

- Як називають снігову зірочку? (Сніжинка).

- Як називають дуже сильний сніг? (Сніжище). (Снігуронька).

- Як називають героїню народної казки, що уособлює сніжну зиму?

- Як називають пташку, яка прилітає до нас з холодами, снігом? (Снігур).

1. Визначте, який метод навчання був використаний учителькою?

2. Запропонуйте варіант використання 3 цієї теми методу на рівні частковопошукової діяльності учнів.

Задача 2. Учням молодших класів на уроці математики пропонують завдання.

1. Заповніть пропуски у запропонованих «магічних» квадратах. Використовуючи картки з цифрами (наприклад, 1, 2, 3, 4, 5, 6, 7, 8, 9), складіть квадрат, щоб сума балів по горизонталі й вертикалі дорівнювала 15.

\begin{tabular}{|c|c|c|}
\hline \multicolumn{3}{|c|}{ A } \\
\hline 4 & 9 & 2 \\
\hline & 5 & \\
\hline 8 & & 6 \\
\hline \multicolumn{3}{|c|}{ Б } \\
\hline \multirow[t]{3}{*}{7} & 2 & \\
\hline & 6 & \\
\hline & 10 & 5 \\
\hline \multicolumn{3}{|c|}{ B } \\
\hline & & \\
\hline & 6 & \\
\hline 3 & 10 & 5 \\
\hline
\end{tabular}

2. Дано «магічний» квадрат:

\begin{tabular}{|c|c|c|}
\hline 5 & 10 & 3 \\
\hline 4 & 6 & 8 \\
\hline 9 & 2 & 7 \\
\hline
\end{tabular}

Складіть подібний квадрат, збільшуючи або зменшуючи нижнє число на кілька одиниць.

1. Який метод навчання використано? 3 якою метою?

2. Які вимоги використання системи вправ реалізовані у цуьому випадку?

Педагогіка вищої та середної иколи. - 2014. - Вип. 42 
Використання проблемних задач та ситуацій у підготовці і проведенні практичних і лабораторних занять формують такі якості особистості майбутнього вчителя, як комунікативність, емпатія, педагогічна інтуїція, самовладання, педагогічний оптимізм, які поєднуються з глибокими теоретичними педагогічними знаннями.

Л. Анісімова [1, с. 146] наголошує, що проблемна задача виконує свої специфічні діï, які наведені в таблиці 1 .

Таблиия 1

\begin{tabular}{|c|c|c|c|}
\hline Етапи & Планування мети & $\begin{array}{c}\text { Діагностування } \\
\text { рівня готовності } \\
\text { студентів }\end{array}$ & $\begin{array}{c}\text { Проектування } \\
\text { навчальних задач }\end{array}$ \\
\hline 1 & $\begin{array}{l}\text { Загальні цілі } \\
\text { інформаційному, } \\
\text { діяльнісному } \\
\text { особистісному та } \\
\text { аспектах }\end{array}$ & \begin{tabular}{lrr}
\multicolumn{2}{l}{ Діагностування } \\
загального & рівня \\
готовності & студентів \\
до сприйняття & нового \\
знання $\quad$ i & до \\
iнтелектуальних & та \\
практичних дій, темпу \\
навчання
\end{tabular} & $\begin{array}{l}\text { Розроблення концепції } \\
\text { управління самостійною } \\
\text { роботою студентів } \\
\text { розв'язання навчальних } \\
\text { педагогічних задач }\end{array}$ \\
\hline 2 & $\begin{array}{l}\text { Ієрархічне } \\
\text { вибудовування } \\
\text { системи навчальних } \\
\text { професійних } \quad \text { задач. } \\
\text { Цільовий } \quad \text { графік } \\
\text { упровадження задач } \\
\text { у навчальний процес } \\
\text { підготовки педагогів }\end{array}$ & $\begin{array}{l}\text { Діагностування } \\
\text { готовності в галузі } \\
\text { конкретного предмета } \\
\text { навчання. Теоретично- } \\
\text { інформаційна } \\
\text { готовність. } \\
\text { Функціонально- } \\
\text { аналітична побудова } \\
\text { нормативної моделі } \\
\text { готовності }\end{array}$ & $\begin{array}{l}\text { Проектування системи, } \\
\text { структурування } \\
\text { iнформації, виявлення } \\
\text { співвідношення між } \\
\text { відомим і невідомим, } \\
\text { проектування } \\
\text { необхідних дій для } \\
\text { розв’язання завдання, } \\
\text { побудова с схеми } \\
\text { регулювання } \\
\text { пізнавальною } \\
\text { діяльністю студентів }\end{array}$ \\
\hline 3 & $\begin{array}{l}\text { Адаптація } \\
\text { предметних цілей } \\
\text { освіти та розвитку } \\
\text { до чинних умов їх } \\
\text { iнтерпретації }\end{array}$ & $\begin{array}{l}\text { Діагностування } \\
\text { індивідуального, } \\
\text { особистісного рівня } \\
\text { готовності } \\
\text { продуктивної } \\
\text { діяльності. } \\
\text { Виявлення внутрішніх } \\
\text { і зовнішніх чинників } \\
\text { педагогічного } \\
\text { середовища }\end{array}$ & $\begin{array}{l}\text { Визначення складу, } \\
\text { обсягу і часу навчальної } \\
\text { роботи на розв’язання } \\
\text { задачі }\end{array}$ \\
\hline
\end{tabular}

Отже, використання педагогічних задач (ситуацій) у навчально-виховному процесі підготовки майбутніх учителів початкових класів має важливе значення. Роль педагогічних задач як засобу дидактичної підготовки переконливо доведена в дослідженнях. Методику вищої школи без цього напряму в роботі викладача не можна вважати сучасною, такою, що відповідає вимогам, що висуваються до підготовки фахівців.

\section{Література}

1. Анісімова Л. С. Проектування педагогічних задач як дидактичного засобу підготовки майбутніх вчителів початкових класів/ Л. С. Анісімова // Вісник 
Черкаського університету: Серія педагогічні науки. - № 165. - С. 144-148. 2. Балл Г. А. Теория учебных задач : Психолого-педагогический аспект / Г. А. Балл. М. : Педагогика, 1990. - 184 с. З. Левина М. М. Технология профессионального педагогического образования : [учеб. пособ.] / М. М. Левина. - М. : Академия, 2001. 270 с. 4. Матюшкин А. М. Проблемные ситуации в мышлении и обучении : [пособ.] / А. М. Матюшкин. - М. : Педагогика, 1972. - 209 с. 5. Махмутов М. И. Проблемное обучение. Основные вопросы теории : [учеб. пособ.] / М. И. Махмутов. - М. : Педагогика, 1975. - 368 с. 6. Низамов Р. А. Дидактические основы активизации учебной деятельности студентов : [пособ.] / Р. А. Низамов. - Казань : Изд-во КГУ, 1995. - 302 с. 7. Омеляненко В. Л. Педагогіка : завдання і ситуації : Практикум: [навч.-метод. посіб.] / В. Л. Омеляненко, А. І. Кузьмінський, Л. П. Вовк. - К. : ЗнанняПрес, 2006. - 423 с. 8. Савченко О. Я. Дидактика початкової освіти : [підручн.] / О. Я. Савченко. - К. : Грамота, 2012. - 504 с. 9. Сухомлинський В. О. Серце віддаю дітям / В. О. Сухомлинський // Вибрані твори : в 5 т. - Т. 3. - К. : Рад. шк., 1977. C. 53-54. 10. Топузов О. М. Проблемне навчання : теорія і практика : [монографія] / О. М. Топузов. - К. : Фенікс, 2007. - 304 с.

УДК 372.881.111.1:37.02

Ірина Сімкова

\section{СУЧАСНИЙ СТАН НАВЧАННЯ МАЙБУТНІХ БАКАЛАВРІВ-ФІЛОЛОГІВ УСНОГО ДВОСТОРОННЬОГО ПЕРЕКЛАДУ В НАУКОВО-ТЕХНІЧНІЙ СФЕРІ}

Сімкова I. О. Сучасний стан навчання майбутніх бакалаврів-філологів усного двостороннього перекладу в науково-технічній сфері.

У статті на основі аналізу, порівняння й узагальнення освітньо-кваліфікаційних характеристик, освітньо-професійних програм, довідника кваліфікаційних характеристик професій працівників та різних зарубіжних стандартів у галузі усного перекладу розглядається сучасний стан навчання майбутніх перекладачів усного перекладу в науково-технічній сфері.

Ключові слова: майбутні філологи, навчання усного перекладу, освітньокваліфікаційна характеристика, освітньо-професійна програма, професійний стандарт.

Симкова И. О. Современное состояние обучения будущих бакалавров-филологов устному двустороннему переводу в научно-технической сфере.

В статье на основе анализа, сопоставления и обобщения образовательноквалификационных характеристик, образовательно-профессиональных программ, справочника квалификационных характеристик профессий служащих и различных зарубежных стандартов в области устного перевода рассматривается современное состояние обучения будущих переводчиков устному переводу в научно-технической сфере.

Ключевые слова: будущие филологи, обучение устному переводу, образовательно-квалификационная характеристика, образовательнопрофессиональная программа, профессиональный стандарт.

Simkova I. O. The current state of future bachelor-philologists training in bilingual interpreting in scientific and technical sphere.

On the ground of analysis, contrast, and unification of educational-qualification 